\title{
Kelimpahan Rumput Laut Di Komunitas Lamun Di Perairan Pulau Nyamuk Kepulauan Karimunjawa
}

\author{
Rio Adista Widodo Putra*, Adi Santoso, Ita Riniatsih \\ Departemen IImu Kelautan, Fakultas Perikanan dan IImu Kelautan, Universitas Diponegoro \\ Jl. Prof.H.Soedarto S.H, Tembalang,Semarang, Jawa Tengah 50275 Indonesia \\ ${ }^{\star}$ Corresponding author, e-mail : rioadistawidodoputra@gmail.com
}

\begin{abstract}
ABSTRAK : Pulau Nyamuk merupakan salah satu pulau yang berada di bagian barat kepulauan Karimunjawa. Rumput laut dan lamun masuk dalam vegetasi pesisir yang ada di Pulau Karimunjawa. Tingginya aktivitas penangkapan ikan oleh nelayan dan rencana pembangunan sarana pariwisata diduga menjadi pemicu tertekannya 2 vegetasi laut tersebut di Pulau Nyamuk. Tujuan dilakukannya penelitian ini adalah mengidentifikasi jenis dan struktur komunitas rumput laut di padang lamun di perairan Pulau Nyamuk Kepulauan Karimunjawa. Materi yang digunakan dalam penelitian ini adalah tumbuhan rumput laut dan lamun. Penelitian ini menggunakan metode deskriptif eksplorasif. Penelitian ini dilakukan pada 3 stasiun yang berbeda di perairan Pulau Nyamuk, yaitu pada stasiun A bagian timur, stasiun B pada bagian barat dan stasiun $\mathrm{C}$ pada bagian utara Pulau Nyamuk. Ditemukan 5 jenis rumput laut jenis Padina australis, Halimeda macroloba, Caulerpa sertulairoides, Caulerpa racemosa dan Sargassum sp. dan 2 spesies lamun jenis Enhalus acoroides dan Halophila ovalis. Rata-rata total tutupan rumput laut adalah 48,61\% sedangkan tutupan lamun adalah 19,94 \%. Nilai indeks keanekaragaman dan keseragaman rumput laut termasuk kategori rendah, kecuali pada perairan utara pulau nilai keanekaragamannya sedang dan nilai keseragamannya tinggi. Sedangkan indeks dominasi terlihat ada spesies rumput laut yang mendominasi pada perairan bagian barat dan timur pulau.
\end{abstract}

Kata kunci : Komposisi; Tutupan; Rumput Laut; Lamun; Asosiasi

\section{Abundance of Seaweed in Seagrass Community In the Nyamuk Islands Karimunjawa Archipelago}

ABSTRACT : Nyamuk Island is one of an island located in the western part of Karimunjawa archipelago. Seaweed and seagraas is a marine vegetation in Nyamuk Island. The highest fishing activities and the development plan of tourism facilities trigger the depressed ecological function these marine vegetation on Nyamuk Island. This study aims to identify the type and structure of the seaweed community in seagrass beds and the environmental factors of aquatic physics that affect the existence of seaweed and seagrass in the waters of Nyamuk Island. This research was conducted on August 29 to September 1, 2017, located at Nyamuk Island, District Karimunjawa, Jepara regency, Central Java Province. The material used in this research was seaweed and seagrass plants. This research parameter data taken directly (in situ). This research uses descriptive exploration method. This research was conducted on 3 different stations in the waters of Nyamuk Island, which is on the east, west and north of Nyamuk Island.Found 5 types of seaweed type Padina australis, Halimeda macroloba, Caulerpa sertulairoides, Caulerpa racemosa and Sargassum sp. and 2 species of seagrass species Enhalus acoroides and Halophila ovalis. The average total seaweed cover is $48.61 \%$ while the seagrass cover is $19.94 \%$. The index value of diversity and uniformity of seaweed is low except in Northern Island, diversity value including medium and uniformity is high, while dominance index is seen that seaweed species dominate on Western and Eastern Island.

Keywords: Composition; Cover; Seaweed; Seagrass; Association 


\section{PENDAHULUAN}

Salah satu ekosistem pesisir adalah ekosistem padang lamun. Ekositem ini terdapat interaksi dari berbagai komunitas vegetasi laut. Salah satu vegetasi laut adalah makroalga yang sangat melimpah di perairan laut dangkal. Habitat makroalga adalah daerah intertidal dan subtidal atau daerah rataan (daerah antara garis pantai hingga tubir) yang bersubstrat pasir atau pecahan karang (Kadi, 2006). Pada prisipnya makroalga hidup di perairan yang masih terkena sinar matahari (Riniatsih et al., 2017).

Rumput laut hidup dengan menempel pada substrat atau pecahan karang (Kadi, 2006). Tomascik,(1997) menyatakan hidupnya rumput laut di ekosistem padang lamun dapat membentuk habitat yang produktif untuk hidup dan berlindung berbagai jenis organisme laut. . Pada umumnya padang lamun memiliki substrat berpasir hasil dari pasir yang terbawa arus dan terperangkap sehingga mengendap pada dasar padang lamun (Wisnubudi dan Wahyuningsih, 2012). Padang lamun sering ditemui di daerah pasang surut terendah (inner intertidal) dan pasang surut tertinggi (upper subtidal). Sebagai penopang keberlangsungan dan kelestarian ekosistem pesisir bersama mangrove dan terumbu karang, rumput laut dan lamun juga memiliki peran tersebut, maka diperlukan penelitian monitoring dan pendataan terhadap rumput laut dan ekosistem padang lamun (Riniatsih et al., 2017).

Menurut Dahuri et al. (2001) mengatakan bahwa studi yang membahas mengenai ekosistem lamun dapat dikatakan masih jarang, padahal kelestarian ekosistem lamun sudah sangat terancam. Fungsi ekologis dari lamun sendiri kini mulai tertekan. Begitu juga dengan pendataan rumput laut yang ada di Pulau Nyamuk. Untuk mengetahui kondisi padang lamun dan komunitas rumput laut di Pulau Nyamuk, maka diperlukan penelitian ini untuk mengetahui kondisi kerapatan, tutupan dan indeks ekologi padang lamun dan komunitas rumput laut di Pulau Nyamuk.

Penelitian ini bertujuan untuk mendapatkan informasi mengenai jenis dan struktur komunitas rumput laut di padang lamun perairan Pulau Nyamuk dan mengetahui faktor lingkungan fisika perairan yang mempengaruhi keberadaan rumput laut dan lamun di perairan Pulau Nyamuk. Diharapkan penelitian ini dapat bermanfaat sebagai data referensi untuk penelitian selanjutanya. Selain itu diharapkan dapat memberikan gambaran mengenai kondisi komunitas rumput laut di padang lamun kawasan tersebut.
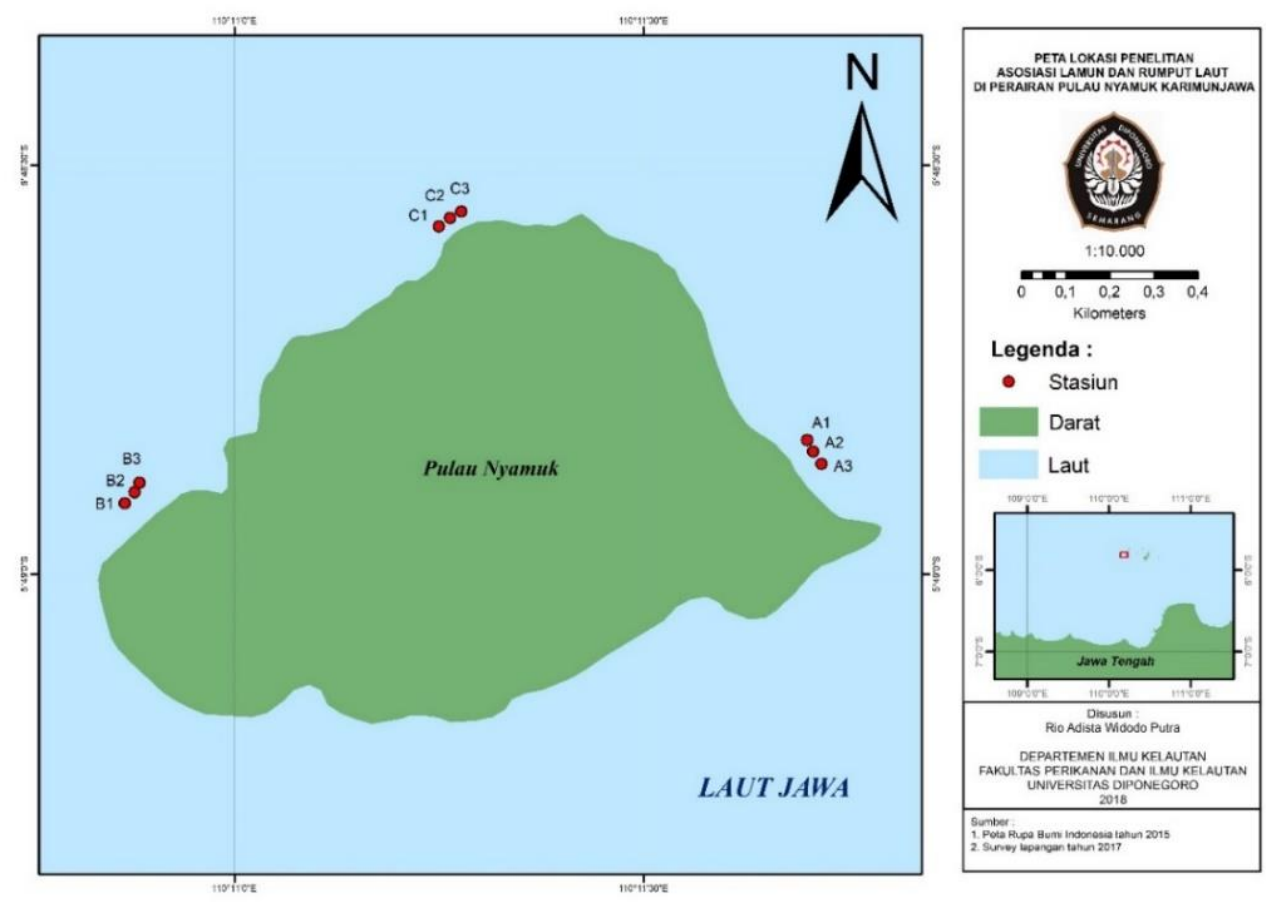

Gambar 1. Stasiun Penelitian di Pulau Nyamuk pada Bagian Timur, Barat dan Utara Pulau Nyamuk 


\section{MATERI DAN METODE}

Materi yang digunakan dalam penelitian ini adalah tumbuhan rumput laut dan lamun yang ditemukan di perairan Pulau Nyamuk, Karimunjawa pada stasiun yang telah ditentukan. Penelitian ini mengambil data berupa jenis, jumlah koloni dan tutupan rumput laut dan berupa jenis, jumlah tegakan dan tutupan lamun serta parameter lingkungan $(\mathrm{pH}$, salinitas, kedalaman dan suhu). Penelitian ini mengambil data parameter yang diambil secara langsung (in situ). Penelitian ini menggunakan metode deskriptif eksplorasif. Metode deskripsif merupakan metode yang mendeskripsikan suatu gejala ataupun fenomena pada saat sekarang berdasarkan fakta-fakta yang tampak atau apa adanya (Sudjana dan Ibrahim, 2001). Metode eksploratif adalah jenis penelitian yang dilakukan untuk menggambarkan keadaan atau status fenomena tertentu (Arikunto, 2002). Maka jika digabungkan, metode deskripsi ekploratif merupakan usaha menyajikan data secara sistematik berdasarkan fakta yang ada di lapangan atas fenomena yang terjadi.

Metode yang digunakan pada penelitian ini adalah metode purposive sampling. Teknik ini merupakan upaya penentuan/pengambilan sampel dengan sengaja dan berdasarkan suatu pertimbangan serta tujuan tertentu (Sugiyono, 2010). Tiga stasiun ini dipilih untuk mewakili tiga kondisi lingkungan yang berbeda. Stasiun A mewakili lingkungan yang sering dikunjungi wisatawan dan kapal wisata, stasiun B mewakili lingkungan yang jarang dikunjungi warga karena stasiunnya yang cukup sulit dijangkau (barat pulau) dan stasiun C mewakili lingkungan yang sangat sering dikunjungi warga karena berbatasan langsung dengan pemukiman (utara pulau). Perairan bagian selatan Pulau Nyamuk tidak ditemukan rumput laut dan lamun sehingga tidak dijadikan stasiun pada penelitian ini.Pengambilan data rumput laut maupun lamun menggunakan transek kuadran ukuran 1x1 meter yang terbagi dari 16 kisi berukuran 25x25 cm. Transek kuadran diletakkan pada masing-masing garis transek pada tiga stasiun tiap stasiun (Gambar 2).

$\mathrm{Hal}$ ini dikarenakan hanya ditemukan rumput laut dan lamun sepanjang 20 meter ke arah tubir. Sedangkan jarak antara garis transek tetap 25 meter sesuai dengan metode seagrass watch. Metode yang digunakan adalah metode line transect quadrant yang mengacu pada metode seagrass watch (Mckenzie dan Campbell, 2003). Pada masing-masing stasiun, ditentukan 3 garis transek. Garis transek ditarik tegak lurus dengan bibir pantai sepanjang 100 meter dari titik awal ditemukan lamun. Pada garis transek sepanjang 100 meter tersebut, ditetapkan transek kuadran tiap 10 meter. Namun, pada penelitian ini pengamatan dilakukan hanya sepanjang 20 meter ke arah tubir sehingga hanya dilakukan pengulangan sebanyak tiga kali.

\section{Analisis Data}

Kerapatan rumput laut pada penelitian ini dihitung dengan rumus (1) sebagai berikut (Odum, 1998) :

$$
\text { Kerapatan Rumput Laut (koloni } \left./ \mathrm{m}^{2}\right)=\frac{\text { jumlah individu jenis a }}{\text { jumlah individu seluruh jenis }}
$$
1998) :

Tutupan rumput laut pada penelitian ini dihitung dengan rumus (2) sebagai berikut (Odum,

$$
\text { Kerapatan Rumput Laut }(\%)=\frac{\text { jumlah individu jenis } a}{\text { jumlah tutupan seluruh jenis }} \times 100 \%
$$

Kerapatan Lamun, Perhitungan kerapatan lamun dalam penelitian ini menggunakan rumus (3) sebagai berikut (Khouw, 2009):

$$
\mathrm{Di}=\frac{\sum n i}{A i}
$$

Keterangan : $\mathrm{Di}=$ Kerapatan lamun jenis-i $\left(\mathrm{ind} / \mathrm{m}^{2}\right) ; \sum \mathrm{ni}=$ Jumlah tunas lamun jenis-i (ind); $\mathrm{Ai}=$ Jumlah luas transek dimana lamun jenis-i ditemukan $\left(\mathrm{m}^{2}\right)$

Persentase Tutupan, Pada setiap jenis yang ditemui, dicatat dan ditentukan nilai titik tengahnya (M), dapat dihitung dengan rumus (4) sebagai berikut : 


$$
\mathrm{C}=\frac{\sum(M i x f i)}{\sum f i}
$$

Keterangan : $\mathrm{C}$ =Persentase penutupan jenis lamun $\mathrm{i}$; $\mathrm{Mi}=$ Prosentase titik tengah dari kelas kehadiran jenis lamun $\mathrm{i}$

Indeks Keanekaragaman, Pada penelitian ini, perhitungan indeks keanekaragaman menggunakan rumus (5) dari Shannon-Wenner (Odum, 1998) :

$$
H^{\prime}=-\sum \frac{\left(\frac{n i}{N}\right)}{\log \left(\frac{n i}{N}\right)}
$$

Keterangan : $\mathrm{H}^{\prime}$ = Indeks keanekaragaman; $\mathrm{Ni}=$ Jumlah individu jenis ke-I; $\mathrm{N}=$ Jumlah individu total; $\mathrm{Pi}=$ Proporsi frekuensi jenis ke-i terhadap jumlah total

Terdapat kriteria dalam penentuan kategori keanekaragaman suatu perairan, yaitu sebagai berikut: $H^{\prime}<1=$ Keanekaragaman rendah; $1 \leq H^{\prime} \leq 3=$ Keanekaragamn sedang; $H^{\prime}>3=$ Keanekaragaman tinggi. Indeks keseragaman dihitung dengan menggunakan persamaan :

$$
\mathrm{E}=\frac{H^{\prime}}{H \max }
$$

Keterangan : $\mathrm{E}=$ Indeks Keseragaman; $\mathrm{H}^{\prime}=$ Indeks Keanekaragaman; $\mathrm{H}^{\prime}$ maks = Indeks Keanekaragaman maksimum

Sedangkan untuk mendapatkan nilai H'maks, dapat dihitung menggunakan persamaan berikut:

$$
H^{\prime} \text { maks }=\log _{2} \text { (jumlah spesies) }
$$

Terdapat kriteria dalam penentuan kategori keseragaman suatu perairan, yaitu : $E<0,4=$ Keanekaragaman rendah; 0,4 $\leq \mathrm{E} \leq 0,6=$ Keanekaragamn sedang; $\mathrm{E}>0,6=$ Keanekaragaman tinggi. Terdapat kriteria dalam penentuan kategori keseragaman suatu perairan, yaitu $0<\mathrm{C}<0,5=$ Tidak ada jenis yang mendominansi dan $0,5<C \leq 1,0=$ terdapat jenis yang mendominansi.
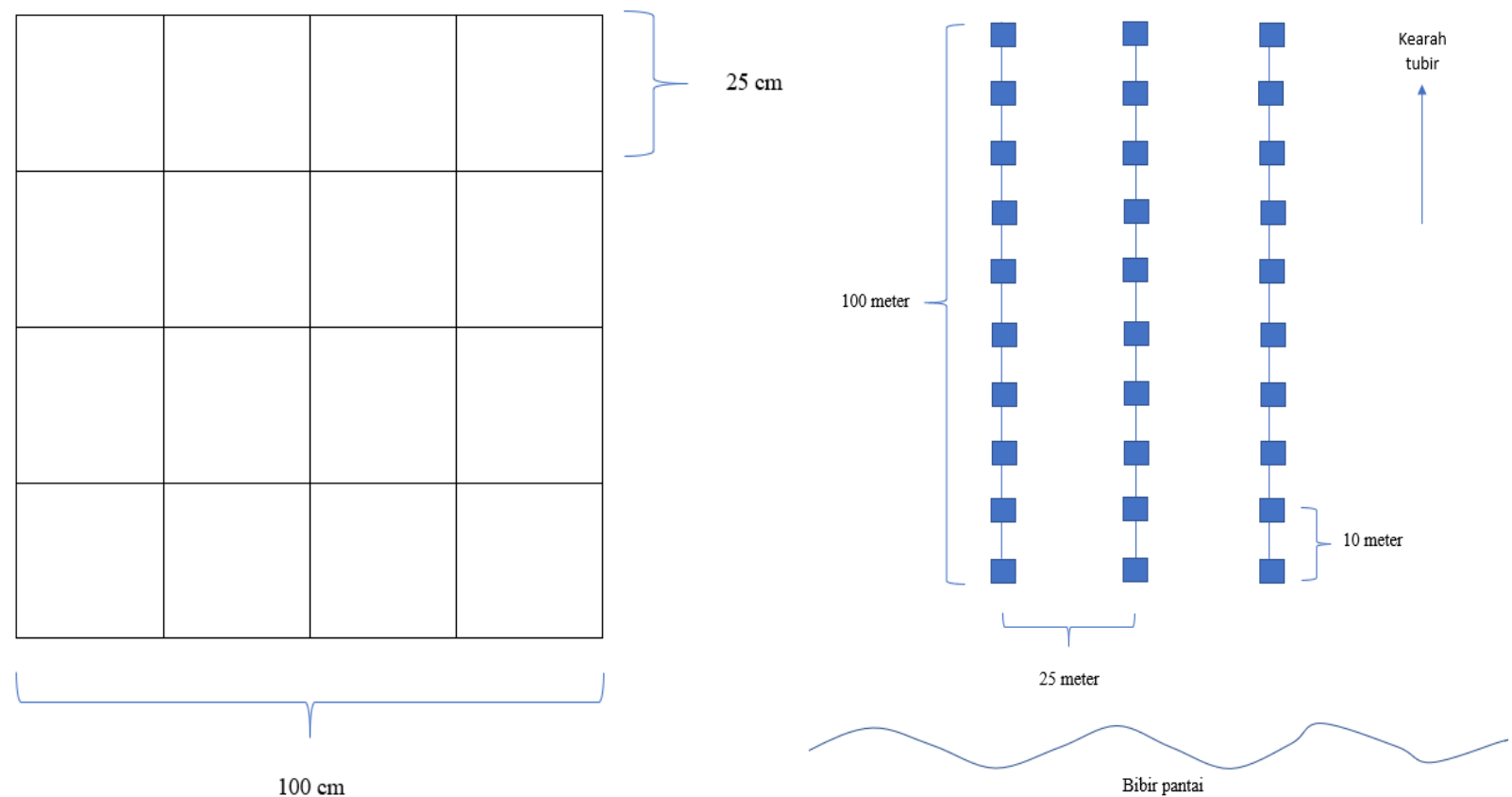

Gambar 2. Transek Kuadran (kiri), Peletakan Transek pada Masing-Masing Garis Transek (kanan) Tabel 1. Kehadiran Jenis Rumput Laut dan Lamun di Stasiun Penelitian 


\begin{tabular}{|c|c|c|c|c|c|c|c|c|}
\hline \multirow{2}{*}{ Stasiun } & \multirow{2}{*}{ Pengulangan } & \multicolumn{5}{|c|}{ Spesies Rumput Laut } & \multicolumn{2}{|c|}{ Spesies Lamun } \\
\hline & & P. a & H. $m$ & C. $\mathrm{s}$ & C. $r$ & S. $s p$ & E. $a$ & H. O \\
\hline \multirow[t]{3}{*}{ A1 } & $p 1$ & - & - & - & - & - & + & - \\
\hline & p2 & - & - & - & - & - & + & - \\
\hline & p3 & - & - & - & - & - & + & - \\
\hline \multirow[t]{3}{*}{$\mathrm{A} 2$} & p1 & - & - & - & - & - & + & - \\
\hline & p2 & - & - & - & - & - & + & - \\
\hline & p3 & + & - & - & - & - & + & - \\
\hline \multirow[t]{3}{*}{ A3 } & p1 & - & - & - & - & - & + & - \\
\hline & p2 & - & - & - & - & - & + & - \\
\hline & p3 & - & - & - & - & - & + & - \\
\hline \multirow[t]{3}{*}{ B1 } & p1 & - & + & - & - & - & - & + \\
\hline & p2 & - & + & - & - & - & - & + \\
\hline & p3 & - & + & - & - & - & - & + \\
\hline \multirow[t]{3}{*}{ B2 } & p1 & - & - & - & - & - & - & + \\
\hline & p2 & - & - & - & - & - & - & + \\
\hline & p3 & - & - & - & - & - & - & + \\
\hline \multirow[t]{3}{*}{ B3 } & p1 & - & - & - & - & - & - & + \\
\hline & p2 & - & - & - & - & - & - & + \\
\hline & p3 & - & - & - & - & - & - & + \\
\hline \multirow[t]{3}{*}{$\mathrm{C} 1$} & $\mathrm{p} 1$ & + & - & + & + & - & - & - \\
\hline & p2 & + & + & + & + & - & - & - \\
\hline & p3 & + & + & + & + & - & - & - \\
\hline \multirow[t]{3}{*}{$\mathrm{C} 2$} & $\mathrm{p} 1$ & + & + & - & - & - & - & - \\
\hline & p2 & + & + & + & + & + & - & - \\
\hline & p3 & + & + & + & + & + & - & - \\
\hline \multirow[t]{3}{*}{ C3 } & $\mathrm{p} 1$ & + & - & + & + & - & - & - \\
\hline & p2 & + & - & + & + & - & - & - \\
\hline & p3 & - & - & - & - & - & - & - \\
\hline
\end{tabular}

\section{HASIL DAN PEMBAHASAN}

Stasiun A1 bertitik koordinat S $05^{\circ} 48^{\prime} 50,5^{\prime \prime}$ - E $110^{\circ} 11^{\prime} 42,2^{\prime \prime}$ stasiun A2 bertitik koordinat S $05^{\circ} 48^{\prime} 51,2$ ' - E $110^{\circ} 11^{\prime} 42,7^{\prime \prime}$ stasiun A3 bertitik koordinat S $05^{\circ} 48^{\prime} 51,9^{\prime \prime}$ - E $110^{\circ} 11^{\prime} 43,2^{\prime \prime}$. Stasiun A merupakan perairan paling timur pada Pulau Nyamuk. Pada stasiun bersubstrat pasir ini ditemukan rumput laut jenis Padina australis dan lamun jenis Enhalus acoroides. Padina australis pada stasiun ini hanya ditemukan pada satu garis transek. Lamun pada stasiun ini hanya ditemukan hingga 20 meter kearah tubir dari titik awal ditemukan.

Stasiun B1 bertitik koordinat S $05^{\circ} 48^{\prime} 54,8^{\prime \prime}-\mathrm{E} 110^{\circ} 10^{\prime} 52,0^{\prime \prime}$ stasiun B2 bertitik koordinat S $05^{\circ} 48^{\prime} 54,0^{\prime \prime}$ - E $110^{\circ} 10^{\prime} 52,6^{\prime \prime}$ stasiun B3 bertitik koordinat S $05^{\circ} 48^{\prime} 53,3^{\prime \prime}$ - E $110^{\circ} 10^{\prime} 53,1^{\prime \prime}$. Stasiun B merupakan perairan bagian barat Pulau Nyamuk. Pada stasiun bersubstrat pasir ini ditemukan rumput laut Padina australis dan lamun jenis Halopila ovalis. Padina australis pada stasiun ini hanya ditemukan pada 1 garis transek. Padang lamun pada stasiun ini tidak rapat. Lamun pada stasiun ini hanya ditemukan hingga 20 meter kearah tubir dari titik awal ditemukan. Stasiun ini terletak lebih dari 30 meter di depan ekosistem mangrove.

Stasiun C1 bertitik koordinat S $05^{\circ} 48^{\prime} 48,9^{\prime \prime}-\mathrm{E} 110^{\circ} 11^{\prime} 15,7^{\prime \prime}$ stasiun C2 bertitik koordinat S $05^{\circ} 48^{\prime} 35,4^{\prime \prime}-\mathrm{E} 110^{\circ} 11^{\prime} 17,0^{\prime \prime}$ stasiun C3 bertitik koordinat S $05^{\circ} 48^{\prime} 35,2$ ' - E $110^{\circ} 11^{\prime} 17,7^{\prime \prime}$. Stasiun $\mathrm{C}$ merupakan perairan bagiat utara Pulau Nyamuk. Perairan ini bersubstrat karang mati, ditemukan banyak rumput laut jenis Caulerpa sertulairoides, Padina australis, Halimeda macroloba, Caulerpa racemose dan Sargassum sp. Namun tidak ditemukan lamun. Rumput laut pada stasiun ini hanya ditemukan hingga 20 meter kearah tubir dari titik awal ditemukan. Vegetasi pantai di stasiun ini didominasi tumbuhan mangrove Rhizophora apiculata. 
Kerapatan rumput laut dan lamun pada 3 stasiun ini cukup signifikan. Hal ini dikarenakan jumlah rumput laut yang ditemukan pada stasiun $\mathrm{A}$ dan $\mathrm{B}$ sedikit dan pada stasiun $\mathrm{C}$ tidak ditemui lamun. Tingkat kerapatan antara rumput laut dan lamun berbanding terbalik sebagai mana tercantumkan pada Gambar 2 dan Gambar 3. Hasil pengamatan \% tutupan rumput laut, didapatkan persentase tutupan rumput laut tertinggi pada stasiun C1 yang mencapai $75 \%$ sedangkan nilai terendah pada stasiun A1, A3, B2 dan B3 yaitu $0 \%$. Hasil pengamatan \% tutupan padang lamun, didapatkan persentase tutupan paling tinggi pada stasiun B3 yang mencapai $51,56 \%$ sedangkan terendah pada stasiun $\mathrm{C} 1, \mathrm{C} 2$ dan $\mathrm{C} 3$ yang bernilai $0 \%$.

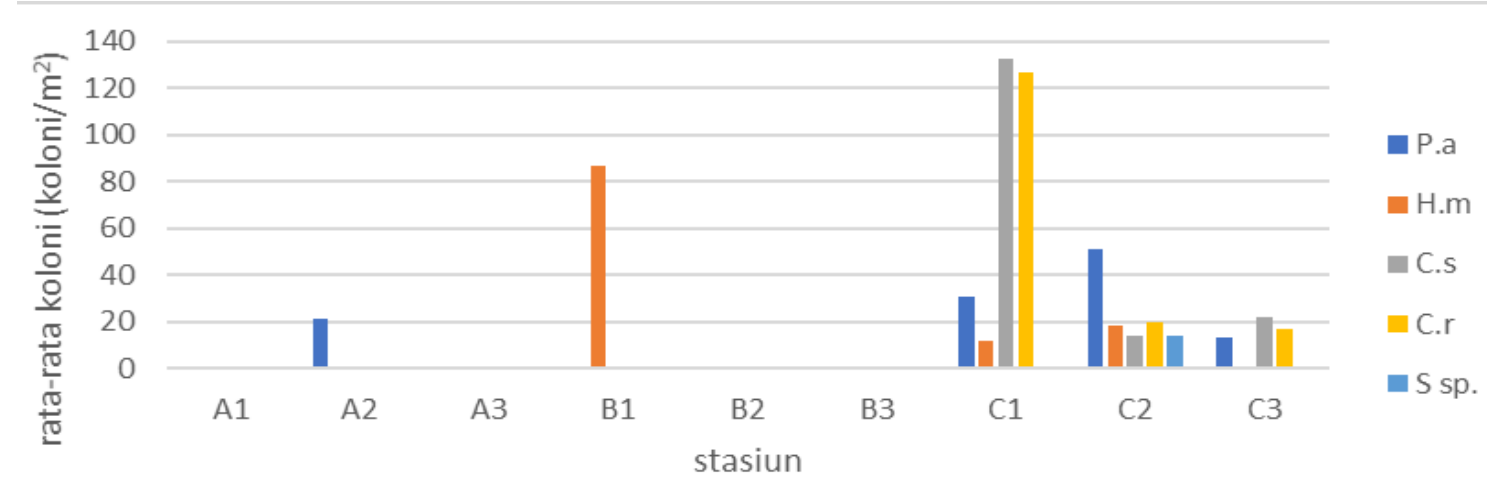

Gambar 2. Tingkat Kelimpahan Rumput Laut di Pulau Nyamuk, Karimunjawa

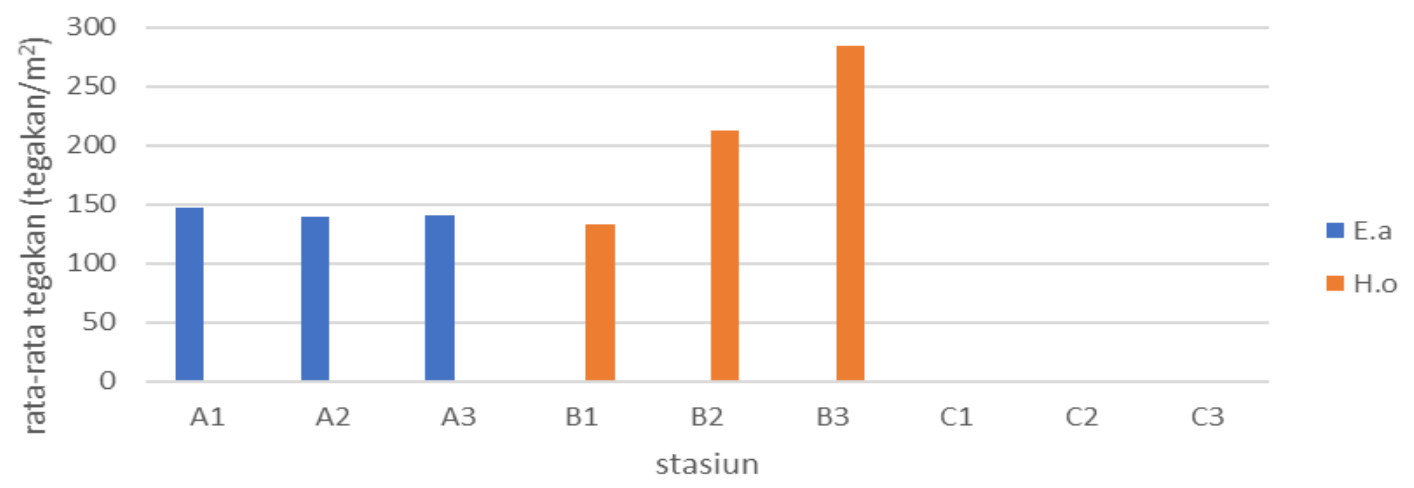

Gambar 3. Tingkat Kelimpahan Lamun di Pulau Nyamuk, Karimunjawa

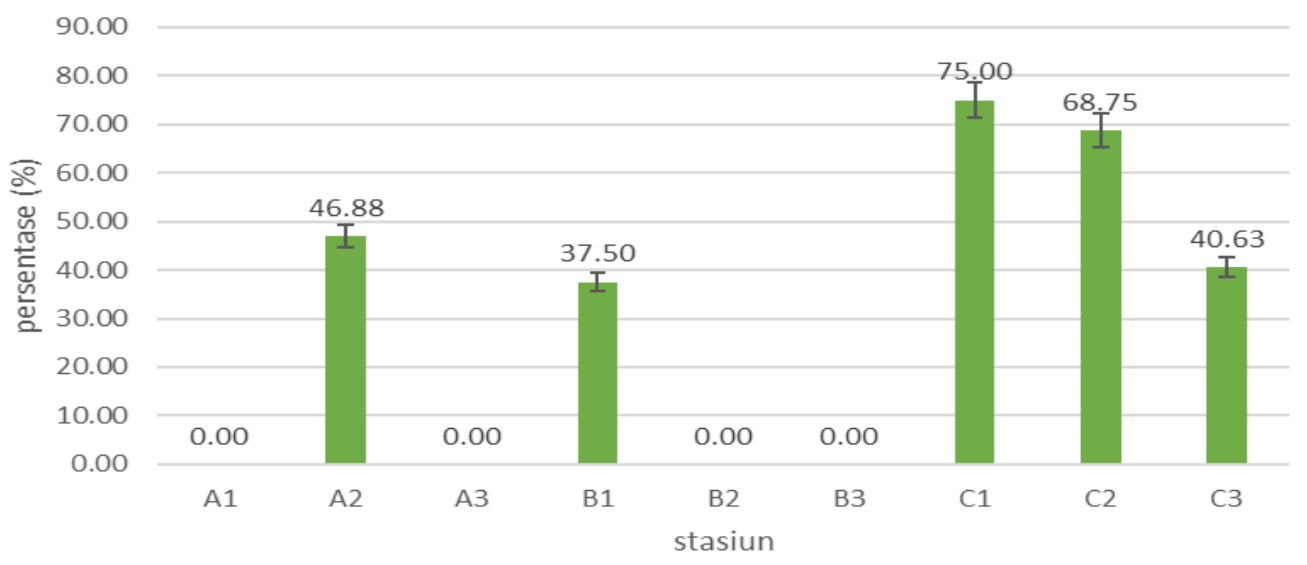

Gambar 4. Tutupan Rumput Laut di Stasiun Penelitian 


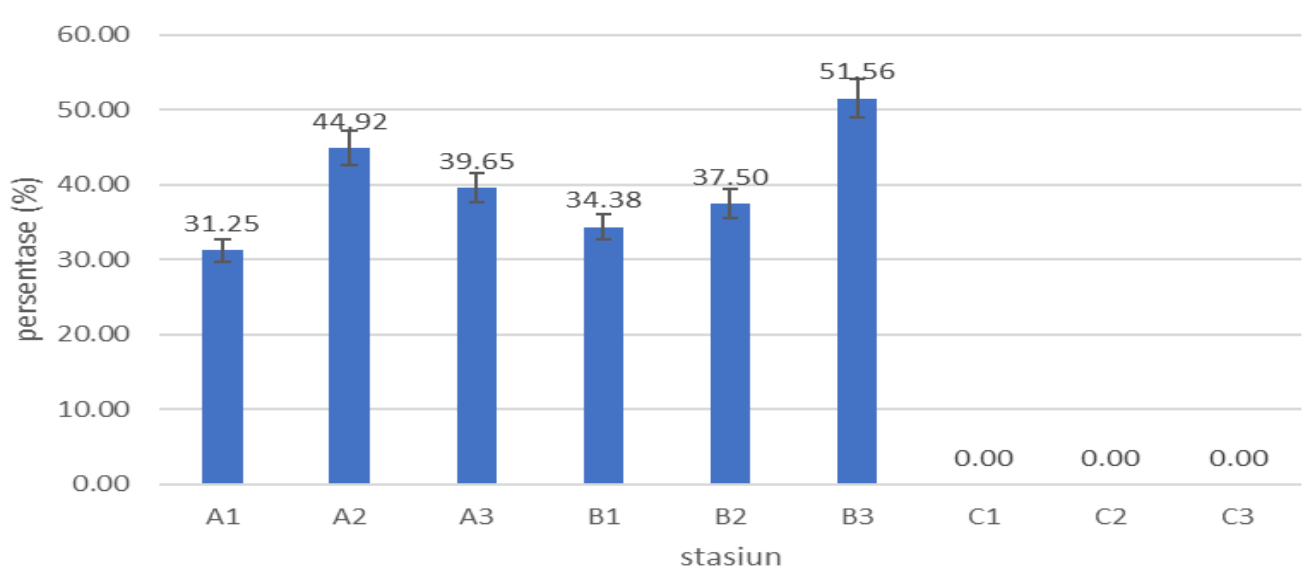

Gambar 5. Tutupan Lamun di Stasiun Penelitian

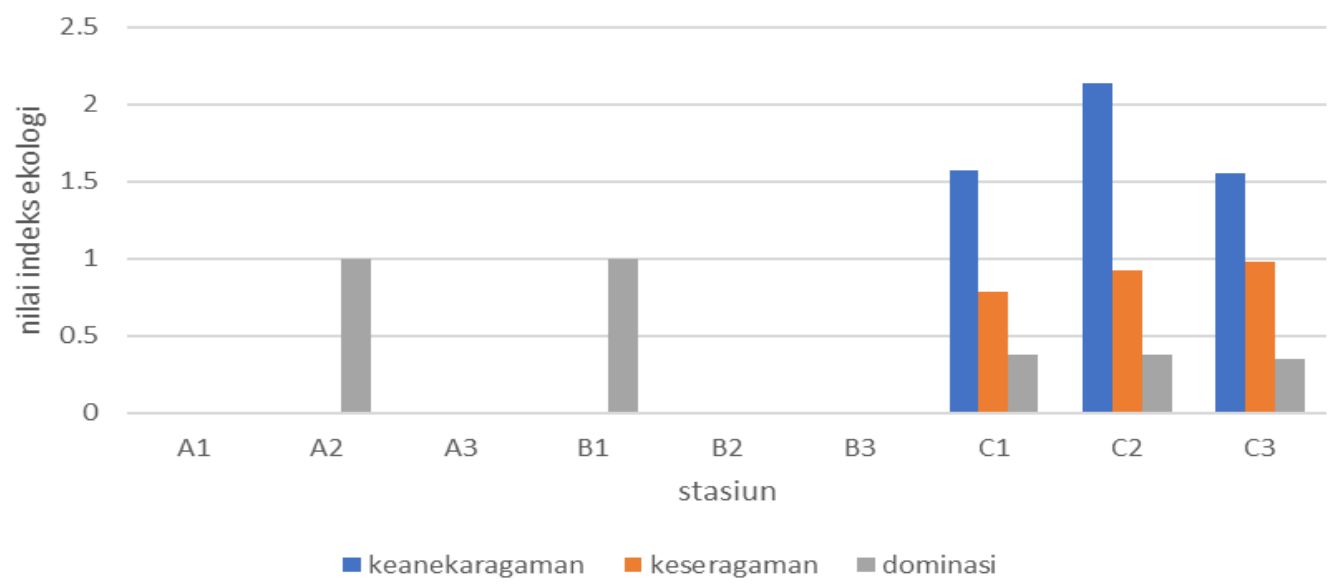

Gambar 6. Struktur Komunitas Rumput Laut di Perairan Pulau Nyamuk, Karimunjawa

Hasil perhitungan indeks ekologi rumput laut di perairan Pulau Nyamuk Karimunjawa tersaji pada Gambar 6. Grafik ini menunjukan pada nilai keanekaragaman dan keseragaman stasiun A dan B berkategorikan rendah. Nilai keanekaragaman stasiun $\mathrm{C}$ berkategorikan sedang, nilai keseragaman stasiun $\mathrm{C}$ berkategorikan tinggi. Nilai dominasi 3 stasiun hanya pada stasiun $\mathrm{A} 2$ dan B1 yang berkategori mendominasi karena ditemukan hanya satu spesies rumput laut pada masing-masing stasiun. Parameter perairan diamati untuk memberikan gambaran kondisi perairan secara umum di masing-masing stasiun tersaji pada tabel 2.

Tingginya nilai tegakan stasiun $\mathrm{B}$ diduga karena adanya hutan mangrove yang membantu memberikan kondisi lingkungan yang baik bagi lamun. Sejalan dengan itu Assa (2015), menyatakan bahwa tingkat kehadiran lamun dipengaruhi oleh kondisi ekosistem sekitarnya termasuk mangrove. Mangrove dapat mengikat sedimen yang masuk kelaut dari daratan, sehingga perairan yang berhadapan dengan hutan mangrove cenderung memiliki substrat pasir. Sejalan dengan itu pada stasiun B hanya ditemukan lamun jenis $H$. ovalis yang memiliki habitat di substrat berpasir (Waycott et al., 2014). Sedangkan pada stasiun C yang memiliki tingkat kehadiran lamun 0 individu/m2 sangat dekat dengan pemukiman warga, sehingga diduga adanya dampak lingkungan yang disebabkan aktivitas manusia. Atmadja et al., (1996) juga menyatakan kehadiran rumput laut pada suatu perairan dapat dipengaruhi oleh beberapa hal, seperti faktor karakteristik lingkungan dan karakteristik lamun itu sendiri. Dalam hal ini diduga adanya pengaruh dari kegiatan warga seperti pembuangan limbah rumah tangga ke laut. Diduga adanya limbah domestik yang membuat stasiun ini tidak menunjang kehidupan lamun. Selain itu tidak semua lamun dapat hidup di substrat pecahan karang seperti di stasiun C. 
Perbedaan komposisi ini diduga dipengaruhi oleh perbedaan substrat yang ada di masingmasing stasiun. Riswandi et al. (2016) menyataan bahwa kondisi komposisi lamun dapat dipengaruhi jenis substrat pada masing-masing stasiun. Terlihat adanya perbedaan komposisi jenis lamun dari masing-masing stasiun penelitian yang cenderung membentuk vegetasi pantai secara mengelompok (Tabel 4). Hal ini menunjukan bahwa lamun memilki reproduksi vegetatif yang lebih dominan daripada reproduksi generatifnya (Rahmawati et al., 2012).

Tabel 2. Parameter Lingkungan Perairan Pulau Nyamuk, Karimunjawa

\begin{tabular}{ccccccc}
\hline Stasiun & Stasiun & $\mathrm{pH}$ & Salinitas $(\mathrm{ppt})$ & Suhu $\left({ }^{\circ} \mathrm{C}\right)$ & Kedalaman $(\mathrm{cm})$ & Substrat \\
\hline $\mathrm{A}$ & $\mathrm{A} 1$ & 7,5 & 34 & 28 & 80 & Pasir \\
& $\mathrm{A} 2$ & 8 & 35 & 28,4 & 70 & Pasir \\
& $\mathrm{A} 3$ & 7 & 35 & 28,5 & 70 & Pasir \\
$\mathrm{B}$ & $\mathrm{B} 1$ & 8 & 33 & 28 & 190 & Pasir \\
& $\mathrm{B} 2$ & 7,5 & 32 & 29 & 180 & Pasir \\
& $\mathrm{B} 3$ & 7 & 33 & 28,8 & 200 & Pasir \\
$\mathrm{C}$ & $\mathrm{C} 1$ & 8 & 34 & 28,7 & 60 & Pecahan karang \\
& $\mathrm{C} 2$ & 8 & 34 & 28,5 & 60 & Pecahan karang \\
& $\mathrm{C} 3$ & 8,5 & 33 & 28,5 & 50 & Pecahan karang \\
\multicolumn{2}{c}{ baku mutu $\left.{ }^{*}{ }^{*}\right)$} & $7,0-8,5$ & $33,0-34,0$ & $28,0-30,0$ & & \\
\hline
\end{tabular}

Nilai kerapatan tertinggi rumput laut pada spesies $C$. sertulairoides yaitu $133 \mathrm{ind} / \mathrm{m} 2$ pada stasiun $\mathrm{C} 1$. Stasiun $\mathrm{C}$ sangat mendukung pertumbuhan rumput laut dikarenakan pada stasiun ini bersubstrat karang mati. Chapman (1975) menyatakan kemampuan bertahan hidup rumput laut salah satunya pada kemampuan holdfast dan substrat yang memudahkan rumput laut melekat. Kemampuan bertahan rumput laut meningkat saat rumput laut melekat pada karang mati daripada pasir. Hal ini dapat membuat holdfast rumput laut melekat lebih kuat di bandingkan melekat pada pasir seperti pada stasiun A dan stasiun B.

Persentase tertinggi tutupan rumput laut di perairan ini adalah jenis $C$. sertulairoides yang mencapai $67,6 \%$. Hal ini dapat dikarenakan ada stasiun $\mathrm{C}$ yang memiliki parameter lingungan yang baik bagi pertumbuhan rumput laut jenis ini. Hal ini sesuai dengan penelitian dari Taylor (1979) menyatakan bahwa rumput laut jenis $C$. sertulairoides tumbuh maksimal pada perairan dangkal tidak lebih dari 10 meter. Selain itu substrat karang mati juga menunjang kehidupan rumput laut ini. Sejalan dengan hal tersebut Fernández \& Cortés (2005) menyatakan bahwa rumput laut jenis ini adalah termasuk rumput laut invasif yang menyebar dengan cepat diatas terumbu karang seperti pada Pantai Pasifik utara di pantai Kosta Rika.

Persentase tutupan lamun tertinggi pada stasiun B3 yaitu 51,56 \%. Hal ini diduga karena pada stasiun B3 mengarah menuju laut lepas. De longh (1996) menyatakan bahwa persentase tutupan lamun semakin mendekati laut lepas semakin rapat, dikarenakan lamun yang selalu terendam air memiliki persentase yang lebih tinggi daripada yang tidak. Pada saat air laut surut, daun lamun akan mengering dan terbakar terpapar sinar matahari. Daun akan rusak dan mempengaruhi persentase lamun. Ini membuktikan bahwa persentase lamun dapat dipengaruhi oleh pasang surut.

Hasil perhitungan struktur komunitas terdapat pada Gambar 6. Dari hasil perhitungan didapat bahwa indeks keanekaragaman dan keseragaman rumput laut berkategori rendah. Nilai ini dikarenakan pada stasiun $A$ dan $B$ hanya terdapat 1 spesies namun nilai indeks keanekaragaman dan keseragaman stasiun $\mathrm{C}$ masing-masing berkategori sedang dan tinggi. Hal ini diduga terjadi karena masing-masing spesies memiliki kecocokan karakteristik lingkungan yang berbeda-beda. Salinitas di stasiun A memiliki nilai yang melebihi baku mutu, diduga hal ini mengakibatkan minimnya rumput laut yang ditemukan di stasiun ini.

Penelitian yang dilakukan oleh Izzati (2018) membutikan bahwa Sargassum sp. dapat menaikan nilai pH. Hal ini dikarenakan ekstrak Sargassum sp. dapat mempercepat pembusukan 
yang disebabkan penumpukan bahan organik di laut. Sama dengan stasiun $C$ yang memiliki nilai $\mathrm{pH}$ yang paling tinggi daripada stasiun $\mathrm{A}$ dan $\mathrm{B}$. Pada stasiun $\mathrm{C}$ dapat diamati

Hasil pengamatan diduga bahwa ada hubungan kompetisi antara lamun dan rumput laut. Terlihat dari perbedaan jumlah yang cukup signifikan pada masing-masing stasiun. Hal ini serupa dengan penelitian yang dilakukan Riniatsih et al. (2017) dan Sureda et al. (2017) yang menyatakan kehadiran rumput laut bisa menentukan \% tutupan jenis lamun distasiun tersebut. Guerriero et al. (1993) menyatakan rumput laut dari famili Caulerpaceae memiliki racun yang berbahaya dalam rantai makanan serta lamun disekitarnya. Hal ini sesuai dengan hasil pengamatan, dimana pada stasiun $\mathrm{C}$ yang banyak ditemukan rumput laut $C$. racemosa dan $C$. sertulairoides tidak ditemukan lamun sama sekali. Diduga adanya metabolit sekunder yang dihasilkan rumput laut ini yang mengakibatkan lamun tidak dapat hidup di stasiun ini.

\section{KESIMPULAN}

Kesimpulan yang dapat didapat dari penelitian ini yaitu, ditemukan 5 jenis rumput laut yaitu Padina australis, Halimeda. macroloba, Caulerpa sertulairoides, Caulerpa racemosa dan Sargassum sp. Ditemukan 2 spesies lamun jenis Enhalus acoroides dan Halophila ovalis. Ratarata total tutupan rumput laut adalah 48,61\% sedangkan tutupan lamun adalah $19,94 \%$. Keanekaragaman dan keseragaman rumput laut dan lamun di Pulau Nyamuk rendah. Ada spesies rumput laut yang mendominasi, namun tidak ada spesies lamun yang mendominasi.

\section{DAFTAR PUSTAKA}

Arikunto, S. 2002. Prosedur Penelitian Suatu Pendekatan Praktek. 5th ed., PT. Rineka Cipta, Jakarta.

Assa, J.D., Wagey, B.T. and Boneka, F.B., 2015. Jenis-jenis ikan di padang lamun pantai Tongkaina. Jurnal Pesisir dan Laut Tropis, 2(1):53-61.

Atmadja, W.S., Kadi, A., Sulistijo \& Rachmaniar. 1996. Mengenal Jenis-Jenis Rumput Laut Indonesia. Puslitbang Oseanografi-LIPI, Jakarta, $190 \mathrm{hlm}$

Chapman, C.J. 1975. Coastal Vegetation. Oxford: Pergamon Press

Dahuri, R., Rais, J., Ginting, S.P. and Sitepu, D.M., 2001. Pengelolaan sumberdaya wilayah pesisir dan lautan secara terpadu. PT. Pradnya Paramita. Jakarta, 328.

De longh, H.H. 1996. Plant Herbivore Interactions Between Seagasses and Dugongs in a Tropical Small Ecosystem. Katholieke Universiteit Nijmegen, p 205.

Fernández, C \& Cortés, J. 2005. Caulerpa sertularioides, a green alga spreading aggressively over coral reef communities in Culebra Bay, North Pacific of Costa Rica. Coral Reefs. 24(1):10.

Guerriero, A., Marchetti, F., D'Ambrosio, M., Senesi, S., Dini, F. and Pietra, F., 1993. New ecotoxicologically and biogenetically relevant terpenes of the tropical green seaweed Caulerpa taxifolia which is invading the Mediterranean. Helvetica Chimica Acta, 76(2):855864.

Izzati, M., 2008. Perubahan Konsentrasi Oksigen Terlarut dan pH Perairan Tambak setelah Penambahan Rumput Laut Sargassum Plagyophyllum dan Ekstraknya. Anatomi Fisiologi, 16(2):60-69

Kadi, A. 2006. Struktur Komunitas makroalga di Pulau Pengelap, Dadap, Abang Besar dan Abang Kecil di Kepulauan Riau. IImu Kelautan. 11(4): 234-240.

Khouw, A.S. 2009. Metode dan Analisa Kuantitatif dalam Bioteknologi Laut. Pusat Pembelajaran dan Pengembangan Pesisir dan Laut. Jakarta

McKenzie, L.J. \& Campbell, S.J. 2003. Manual for Community (Citizen) Monitoring of Seagrass Habitat. Wester Pasific Edition. Seagrass Wach. Department of Primary Industries Queensland. Australia.

Odum, E.P. 1998. Dasar-dasar Ekologi. Terjemahan Tjahjono Samingan. Edisi. Ketiga. Yogyakarta: Universitas Gadjah Mada

Rahmawati, S., Fahmi, F. and Yusup, D.S., Komunitas Padang Lamun dan Ikan Pantai di Perairan Kendari, Sulawesi Tenggara (Seagrass and Coastal Fish Communities in Kendari Waters, South-East Sulawesi). IImu Kelautan: Indonesian Journal of Marine Sciences, 17(4):190-198. 
Riniatsih, I., Munasik, M., Suryono, C.A., Azizah, R., Hartati, R., Pribadi, R. \& Subagiyo, S., 2017. Komposisi Makroalga Yang Berasosiasi Di Ekosistem Padang Lamun Pulau Tumpul Lunik, Pulau Rimau Balak Dan Pulau Kandang Balak Selatan, Perairan Lampung Selatan. Jurnal Kelautan Tropis, 20(2):117-123.

Riswandi, A.D., Melani, W.R. \& Putra, R.D. 2016. Kajian Tutupan Lamun Berdasarkan Jenis Substrat Di Perairan Desa Sebong Pereh Kecamatan Teluk Sebong. Repository Tugas Akhir Mahasiswa. Universitas Maritim Raja Ali Haji

Sudjana, N. \& Ibrahim. 2001. Penelitian Dan Penilaian Pendidikan. PT. Sinar Baru Algensindo, Bandung.

Sugiyono. 2010. Metode Penelitian Kuantitatif Kualitatif dan RND. PT. Alfabeta, Bandung.

Sureda, A., Tejada, S., Capó, X., Melià, C., Ferriol, P., Pinya, S. \& Mateu-Vicens, G.,. 2017. Oxidative Stress Response in the Seagrass Posidonia oceanica and the Seaweed Dasycladus vermicularis associated to the Invasive Tropical Green Seaweed Halimeda incrassata. Science of the Total Environtment, 601: 918-925.

Taylor, W.R. 1979. Marine algae of the eastern tropical and subtropical coasts of the Americas. Univ. Michigan Press. Ann Arbor, MI. USA. 870 pp.

Tomascik, T., 1997. The ecology of the Indonesian seas. Oxford University Press.

Waycott, M., McMahon, K., Mellors, J., Calladine, A. \& Kleine, D. 2004. A Guide to Tropical Seagrasses of the Indo-West Pacific. James Cook University, Townsville-Queensland Australia

Wisnubudi, G. \& Wahyuningsih, E. 2012. Kajian Ekologis Ekosistem Sumberdaya Lamun dan Biota Laut Asosiasinya di Pulau Pramuka, Taman Nasional Laut Kepulauan Seribu (TNKpS). Universitas Nasional : Jakarta 